\title{
Assessment of air pollution status during COVID-19 lockdown (March-May 2020) over Bangalore City in India
}

\author{
K. C. Gouda $\cdot$ Priya Singh $\cdot$ Nikhilasuma P $\cdot$ Mahendra Benke $\cdot$ \\ Reshama Kumari · Geeta Agnihotri · Kiran M Hungund · Chandrika M • \\ Kantha Rao B $\cdot$ Ramesh V $\cdot$ Himesh S
}

Received: 27 January 2021 / Accepted: 31 May 2021 / Published online: 8 June 2021

(C) The Author(s), under exclusive licence to Springer Nature Switzerland AG 2021

\begin{abstract}
The coronavirus disease 2019 (COVID19), which became a global pandemic by March 2020, forced almost all countries over the world to impose the lockdown as a measure of social distancing to control the spread of infection. India also strictly implemented a countrywide lockdown, starting from 24 March to 12 May 2020. This measure resulted in the reduction of the sources of air pollution in general: industrial, commercial, and vehicular pollution in particular, with visible improvement in ambient air quality. In this study, the impact of COVID-19 lockdown on the ambient concentration of air pollutants over the city of Bangalore (India) is assessed using Continuous Ambient Air Quality Measurement (CAAQM) data from 10 monitoring
\end{abstract}

K. C. Gouda $(\square) \cdot$ P. Singh · N. P · M. Benke

R. Kumari · K. B · H. S

CSIR Fourth Paradigm Institute, Wind Tunnel Road,

Bangalore, India

e-mail:kcgouda@csir4pi.in

\section{G. Agnihotri}

Meteorological Centre Bangalore, India Meteorological

Department, Bangalore, India

\section{K. Hungund}

Karnataka State Remote Sensing Application Centre,

Bangalore, India

C. $\mathrm{M}$

Jain University, Bangalore, India

R. V

Karnataka State Pollution Control Board, Bangalore, India stations spread across the city. The data was obtained from Central Pollution Control Board (CPCB) and Karnataka State Pollution Control Board (KSPCB). The analysis of the relative changes in the ambient concentration of six major air pollutants $\left(\mathrm{NO}, \mathrm{NO}_{2}, \mathrm{NO}_{\mathrm{X}}, \mathrm{PM}_{2.5}\right.$, $\mathrm{O}_{3}$, and $\mathrm{SO}_{2}$ ) has been carried out for two periods: March-May 2020 (COVID-19 lockdown) and the corresponding period of 2019 during when there was no lockdown. The analysis revealed significant reduction in the concentration of ambient air pollutants at both daily and monthly intervals. This can be attributed to the reduction in sources of emission; vehicular traffic, industrial, and other activities. The average reduction in the concentration of $\mathrm{NO}, \mathrm{NO}_{2}, \mathrm{NO}_{\mathrm{X}}, \mathrm{PM}_{2.5}$, and $\mathrm{O}_{3}$ between 01 March and 12 May 2020 was found to be $63 \%, 48 \%, 48 \%, 18 \%$, and $23 \%$ respectively when compared to the same period in 2019. Similarly, the comparative analysis of pollutant concentrations between pre-lockdown (01-23 March 2020) and lockdown (24 March-12 May 2020) periods has shown a huge reduction in the ambient concentration of air pollutants, $47.3 \%(\mathrm{NO}), 49 \%\left(\mathrm{NO}_{2}\right), 49 \%\left(\mathrm{NO}_{\mathrm{X}}\right)$, $10 \%\left(\mathrm{SO}_{2}\right), 37.7 \%\left(\mathrm{PM}_{2.5}\right)$, and $15.6 \%\left(\mathrm{O}_{3}\right)$, resulting in improved air quality over Bangalore during the COVID19 lockdown period. It is shown that the strict lockdown resulted in a significant reduction in the pollution levels. Such lockdowns may be useful as emergency intervention strategies to control air pollution in megacities when ambient air quality deteriorates dangerously.

Keywords COVID-19 pandemic - Air pollutants . Particulate matter $\cdot$ Nitrogen oxides $\cdot$ Sulphur dioxide 


\section{Introduction}

The outbreak of coronavirus disease 2019 (COVID19) reported to be originated in Wuhan, China, in late December 2019 (Li et al., 2020; Lewis, 2020; Morawska $\&$ Cao, 2020) became a global pandemic by March 2020 as declared by the World Health Organization (WHO) on 11 March 2020 (2020). The global health emergency led to the call for strict shutdown with many measures, like curfews, lockdown, and air travel restrictions, which resulted in disruption of social and economic activities with huge economic losses (Leggett, 2020). The reduction of anthropogenic activities during the COVID-19 outbreak played a key role in significantly reducing air pollution and improving ambient air quality (He et al., 2020; Isaifan, 2020) in various parts of different countries. He et al. (2020) also found that highly industrialized and colder cities experienced a larger reduction in air pollution levels.

Nitrogen dioxide $\left(\mathrm{NO}_{2}\right)$, nitric oxide $(\mathrm{NO})$, sulphur dioxide $\left(\mathrm{SO}_{2}\right)$, and particulate matter $\left(\mathrm{PM}_{2.5}\right.$ and $\left.\mathrm{PM}_{10}\right)$ are some of the major ambient air pollutants in urban and industrial environments contributing to air pollution and deteriorating air quality. $\mathrm{NO}_{2}$ is responsible for catalysing the ozone $\left(\mathrm{O}_{3}\right)$ and acts as a precursor to inorganic aerosols, with consequences for human health (Atkinson et al., 2018; Faustini et al., 2014; Lelieveld et al., 2015; Myhre et al., 2013). Various studies have also demonstrated the role of these pollutants in severe health-related problems like respiratory and cardiovascular disorders, hypertension, and lung cancer in human beings (Agrawal et al., 2006; Humbal et al., 2019; Le Tertre et al., 2002; Koken et al., 2003; Persinger et al., 2002; Arden Pope et al., 2004; Saeha et al., 2020). Sulphur dioxide is the major precursor for the nucleation formation of particles in the atmosphere, which in turn leads to increased human exposure to ultra-fine particles in high-density population zones (Kulmala et al., 2004).

Meteorological factors such as wind speed, precipitation, and the height of the atmospheric boundary layer do play an important role in determining the ambient concentration of air pollutants for a given rate of emissions at source (Singal \& Prasad, 2005; Tayanc, 2000). The wind speed also leads to greater dispersion of atmospheric pollutants (Holzworth, 1967; Shair, 1974); similarly, temperature also has a direct impact on the ambient air quality (Bashir et al., 2020). Generally, the excess concentration of greenhouse gasses controls the temperature variation in the lower atmosphere. The accumulation of $\mathrm{CO}$, $\mathrm{NO}_{2}, \mathrm{SO}_{2}, \mathrm{PM}_{10}$, and $\mathrm{PM}_{2.5}$ in lower atmosphere modifies the intensity of surface air temperature (Global Carbon Project, 2020). The two particulate pollutants $\mathrm{PM}_{10}$ and suspended particulate matter (SPM) show a negative correlation with rainfall, humidity, and wind speed during the study period (March-May 2020) which is known to be related to atmospheric washout. Higher concentrations are normally recorded in the winter seasons for both particulate pollutants (Vijay Bhaskar \& Mehta, 2010).

During March-May 2020, India faced the COVID19 crisis with the number of cases increasing exponentially (Gouda et al., 2020; Venkata et al., 2020). As exposure to air pollution could increase vulnerability and have detrimental effects on the prognosis of COVID-19 patients, it is important to estimate air pollution levels and their impact on the spread of infectious diseases (Cui et al., 2003; Morales et al., 2009). To prevent the rapid transmission of coronavirus, a countrywide lockdown was enforced in India on 24 March 2020 and continued till 12 May 2020. The lockdown led to a reduction in vehicular traffic and related emission of pollutants. In recent times, several studies have highlighted the impact of lockdown due to COVID-19 on atmospheric pollution over India (Bera et al., 2020; Devara et al., 2020; Mahato et al., 2020; Sharma et al., 2020; Gautam, 2020). Unlike other pollutants, $\mathrm{SO}_{2}$ seems to have increased during the lockdown, and this could be due to no restriction on power plants (Sharma et al., 2020). There was a reduction of particulate matter in the atmosphere during the lockdown in New Delhi and Kolkata (Mitra et al., 2020; Bera et al., 2020). The present study is an attempt to assess the status of air pollution during the lockdown in the city of Bangalore using the ground-based observation obtained from the Central Pollution Control Board (CPCB) and Karnataka State Pollution Control Board (KSPCB).

Many cities in India have witnessed a high level of air pollution (Garaga et al., 2018; Kota et al., 2018; Mukherjee \& Agrawal, 2018) in the past. The rapid growth in the industrial, power, and transportation sectors have contributed to the rapid increase in ambient air pollution (AAP) levels in India (Gordon et al., 2018). Bangalore, the capital city of Karnataka is also witnessing very high levels of air pollution due to increased population and traffic. Bangalore 
$\left(12^{\circ} 0.40^{\prime} \mathrm{N}, 13^{\circ} 0.15^{\prime} \mathrm{N}, 77.20^{\circ} \mathrm{E}, 77.50^{\circ} \mathrm{E}\right)$, shown in Fig. 1, is located in the southern part of the state of Karnataka, covering an area of $741 \mathrm{~km}^{2}$. The estimated population of the city is about 12.34 million which makes Bangalore the 24th most populous city in the world with a population density of about $4000 / \mathrm{km}^{2}$. The city is located at an elevation of $900 \mathrm{~m}$ above mean sea level and enjoys a moderate climate thorough out the year with temperature ranging from 15 to $36{ }^{\circ} \mathrm{C}$, and the average annual rainfall of around $1288 \mathrm{~mm}$. There has been an increasing trend in air pollution over the years due to rapid urbanization, traffic, industry, and related economic and developmental activities (CPCB, 2010, 2014). Earlier studies revealed that the air quality of the city is within acceptable limits set by CPCB, but there is an increasing trend in $\mathrm{NO}_{2}$ and SPM over Bangalore (CPCB, 2010). The major sources of air pollution are; road dust re-suspension, open waste burning, vehicular emission, and diesel generators used in industries (Guttikunda et al., 2019). People often spend more time in traffic and get exposed to air pollution which contributes to increased chronic diseases related to the lungs and heart. Like other parts of the globe, COVID-19 also reached Bangalore, and the first positive case was reported on 8 March 2020, and the number of cases rose to 200 in 2 months (https:// www.mohfw.gov.in). During COVID-19 lockdown imposed by the Government of India and the State Government of Karnataka, roads were deserted with hardly any traffic except for essential and emergency services. All outdoor and commercial activates were closed down.

In this study, an attempt is made to assess the impact of COVID-19 lockdown on the ambient concentration of air pollutants like $\mathrm{PM}_{2.5}, \mathrm{NO}_{\mathrm{X}}, \mathrm{NO}_{2}, \mathrm{NO}, \mathrm{SO}_{2}$, and $\mathrm{O}_{3}$ over the city of Bangalore for the period of 50 days between 24 March and 12 May 2020.

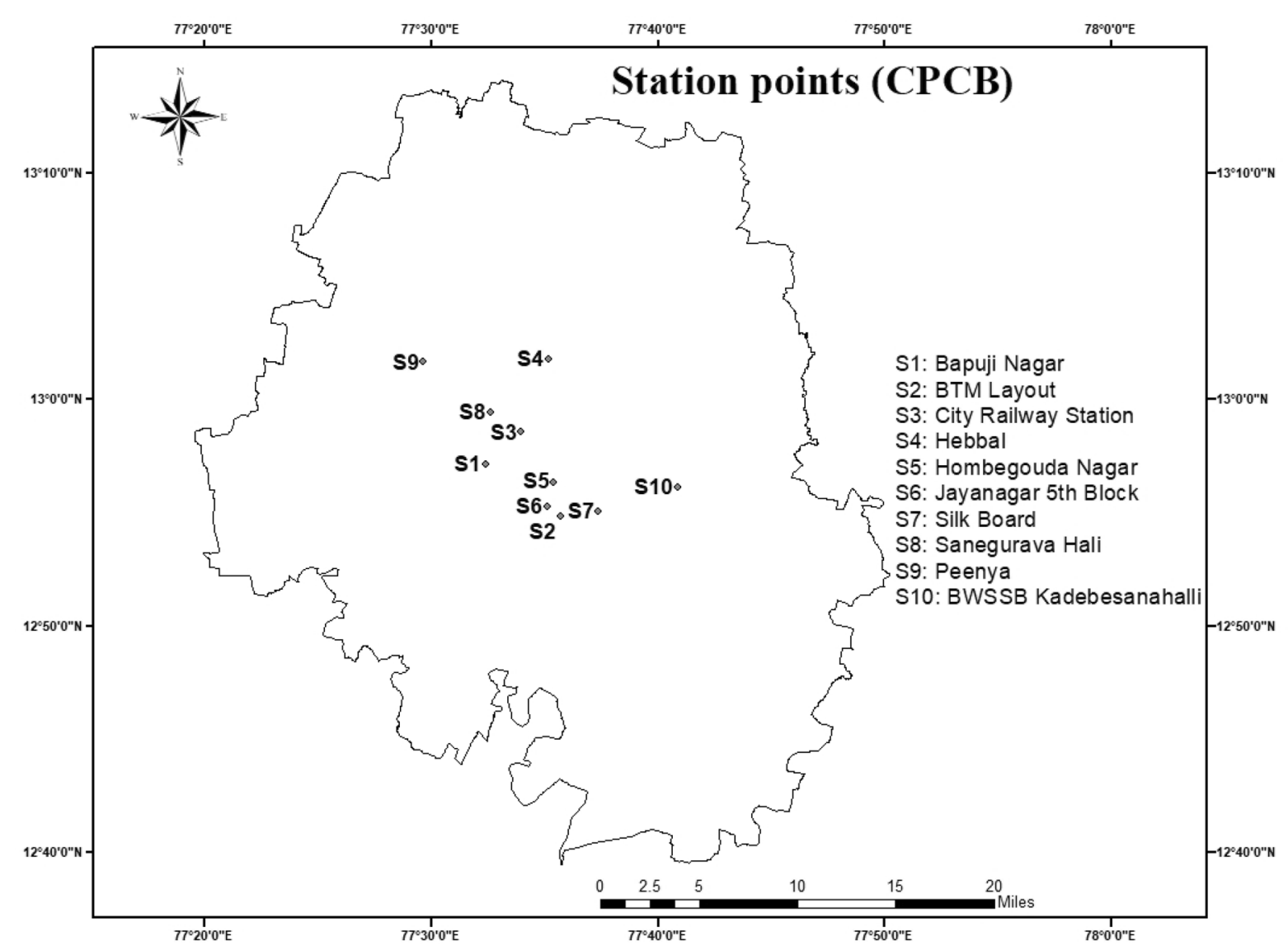

Fig. 1 Map of Bangalore showing the locations of air quality monitoring station by CPCB and KSPC 


\section{Materials and method}

In this study, we have considered the COVID-19 lockdown for the period 24 March-12 May 2020 (50 days) to assess the impact of lockdown on the ambient concentration of the atmospheric pollutants, $\mathrm{PM}_{2.5}, \mathrm{NO}_{\mathrm{X}}$, $\mathrm{NO}_{2}, \mathrm{NO}, \mathrm{SO}_{2}$, and $\mathrm{O}_{3}$, over the city of Bangalore. The data (daily average) on air pollutant concentration $(\mu \mathrm{g} /$ $\mathrm{m}^{3}$ ) was obtained from the CPCB and KSPCB for the period between March and May (for the years 2019 and 2020). The CPCB established the national Ambient Air Quality Monitoring (AAQM) program in 1984 to monitor ambient air quality (Nasir et al., 2016). The monitoring of pollutants at CPCB stations is generally carried out daily with 4-hourly sampling for gaseous pollutants and 8-hourly sampling for $\mathrm{PM}_{2.5}$. The detailed information like siting criteria, measurement techniques, and QA/QC procedures followed are reported in several earlier works (CPCB, 2003a, b; 2010). Ambient air pollutant measurements from 10 locations across the city of Bangalore are used in this analysis. These stations are listed in Table 1 as $\mathrm{S} 1, \mathrm{~S} 2, \mathrm{~S} 3, \ldots, \mathrm{S} 10$, and the exact locations are marked in Fig. 1. Table 1 also describes the location category like commercial, industrial, and railway station. The daily meteorological measurements (temperature, rainfall, humidity, and wind speed) are being collected from the Indian Meteorological Department, Bangalore, and the daily variability is analysed during the lockdown period.

The phase-wise lockdown in India was imposed in 4 phases, i.e., lockdown 1 ( 24 March-14 April 2020), lockdown 2 (15 April-03 May 2020), lockdown 3 (4-17 May 2020), and lockdown 4 (18-31 May 2020). In lockdown 1, the guidelines issued by the Government of India made it mandatory to close offices of private, public, and government sector; schools, colleges, transportation; hotels and recreation facilities; and barred public meetings and private functions. However, there were exceptions for essential services, defence sector, post offices, disaster management, electricity, water, sanitation, hospitals, banks, print and electronic media, telecommunications, and some other emergency services (with a restriction on the number of employees in the workplace). In lockdown 2, most of the restrictions remain unchanged, but some relaxations were issued as per Sates/UTs/district administration. In lockdown 3, the

Table 1 Location of air quality monitoring stations

\begin{tabular}{|c|c|c|c|c|}
\hline Station code & Air quality monitoring Station name & Location category & $\begin{array}{l}\text { Elevation ( } \mathrm{m} \text { above } \\
\text { MSL) }\end{array}$ & $\begin{array}{l}\text { Latitude and } \\
\text { longitude }\end{array}$ \\
\hline $\mathrm{S} 1$ & Bapuji Nagar, & Commercial & 853 & $\begin{array}{l}12.956 \mathrm{~N} \\
77.539 \mathrm{E}\end{array}$ \\
\hline $\mathrm{S} 2$ & BTM Layout, & Commercial & 908 & $\begin{array}{l}12.916 \mathrm{~N} \\
77.610 \mathrm{E}\end{array}$ \\
\hline S3 & CITY Railway Station* & Railway station & 935 & $\begin{array}{l}12.764 \mathrm{~N} \\
76.571 \mathrm{E}\end{array}$ \\
\hline S4 & Hebbal* & Industrial & 903 & $\begin{array}{l}13.035 \mathrm{~N} \\
77.597 \mathrm{E}\end{array}$ \\
\hline S5 & Hombegowda Nagar & Commercial & 910 & $\begin{array}{l}12.937 \mathrm{~N} \\
77.594 \mathrm{E}\end{array}$ \\
\hline S6 & Jayanagar 5th Block* & Commercial & 919 & $\begin{array}{l}12.917 \mathrm{~N} \\
77.583 \mathrm{E}\end{array}$ \\
\hline S7 & Silk Board* & Industrial & 887 & $\begin{array}{l}12.917 \mathrm{~N} \\
77.621 \mathrm{E}\end{array}$ \\
\hline S8 & Sanegurava Hali* & Commercial & 893 & $\begin{array}{l}12.990 \mathrm{~N} \\
77.544 \mathrm{E}\end{array}$ \\
\hline S9 & Peenya & Industrial & 910 & $\begin{array}{l}13.028 \mathrm{~N} \\
77.519 \mathrm{E}\end{array}$ \\
\hline S10 & BWSSB Kadabesanahalli & Industrial & 878 & $\begin{array}{l}12.939 \mathrm{~N} \\
77.695 \mathrm{E}\end{array}$ \\
\hline
\end{tabular}

\footnotetext{
*The Continuous Ambient Air Quality Monitoring Stations (CAAQMS) where the measurements are carried out manually using
} instruments under National Ambient Air Quality Monitoring Programme (NAMP) of Government of India 
movement of non-essential services (public transportation with restricted number of passengers, food delivery, etc.) were prohibited between 7 p.m. and 7 a.m. (night curfew), but allowed between 7 a.m. and 7 p.m.

Specific guidelines were also issued to different zones, red, orange, and green, depending on the number of COVID-19 cases of the zone. In Lockdown 4, different modes of transportation (except in containment zones), salons, liquor shops, markets, and inter-state travelling (with a permit from the state government) were allowed with restrictions. Night curfew was continued (Ministry of Health and Family Welfare, Government of India COVID-19 India dashboard, 2020). The division of zones was removed in Karnataka, and strict rules were implemented on containment zones. All the shops (except for shopping malls, cinema halls, and hotels) were allowed to function between 7 a.m. and 7 p.m., and a complete lockdown was imposed on Sundays (State
Disaster Management Authority: Government of Karnataka, Karnataka COVID 19 Dashboard, 2020).

In this work, to know the change in pollutant concentrations over 10 monitoring stations, we used two different methods of analysis. (a) The change in pollutant concentration between two warm seasons of 2019 and 2020 for the period of 3 months (March to May). (b) The changes in concentration between each phase of the lockdown and total lockdown period (24 March-12 May 2020) are compared with the corresponding pollutant concentration of the pre-lockdown period (01-23 March 2020).

The relative change in concentration (CC) in 2020 summer w.r.t. the year 2019 summer is computed as follows

$C C(i)=\frac{\operatorname{Conc}(i, 2020)-\operatorname{Conc}(i, 2019)}{\operatorname{Conc}(i, 2019)} \times 100$

where $i$ is the day or month in each year.

(b)
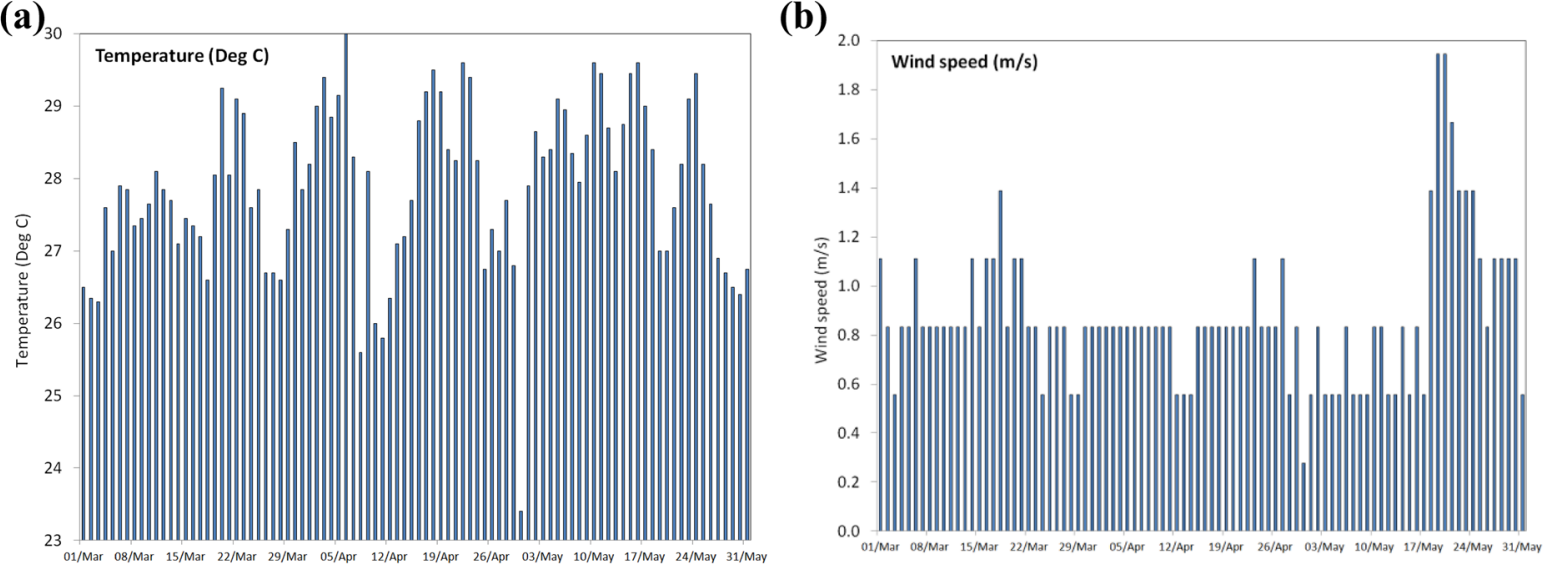

(c)

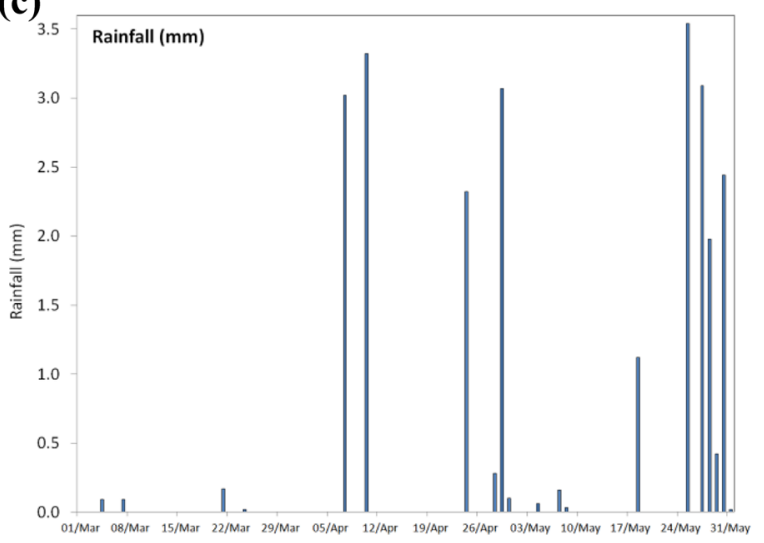

(d)

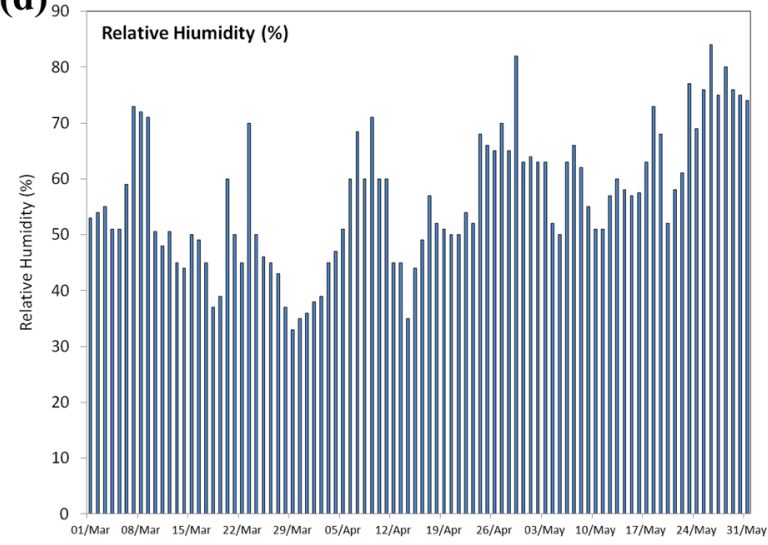

Fig. 2 Daily time series of major meteorological parameters a temperature, $\mathbf{b}$ wind speed, $\mathbf{c}$ rainfall, and $\mathbf{d}$ relative humidity over Bangalore during 01 March to 31 May 2020 
Similarly, the relative change in concentration in lockdown (CCL) w.r.t. pre-lockdown is computed as

$C C L(i)=\frac{\text { Conc }(\text { lockdown })-\text { Conc }(\text { prelockdown })}{\text { Conc }(\text { prelockdown })} \times 100$

where Conc(pre-lockdown) is the pollutant concentration averaged over the pre-lockdown period (01-23 March, 2020) and Conc(lockdown) is the pollutant concentration averaged over the lockdown periods (lockdown 1, lockdown 2, etc.).

$C C(i)$ and $C C L(i)$ are computed for all the stations. The pollutant concentration values for entire city of Bangalore are obtained by taking the mean over 10 stations. The trends are computed using linear regression over the time series data.

\section{Results and discussion}

The daily variation in the major meteorological parameters such as temperature, wind speed, and rainfall are analyzed over the city of Bangalore using the observed data obtained from the India Meteorological Department. The analysis was carried out for the period of 3 months (01 March-31 May 2020) covering different stages of lockdown during COVID-19 and preCOVID-19 as reference period (Fig. 2). The daily mean temperature varied between 23.4 and $30{ }^{\circ} \mathrm{C}$, the range of relative humidity was from 33 to $84 \%$, and the average observed wind speed varied between 0.2 and $1.9 \mathrm{~m} / \mathrm{s}$ during the period of analysis over the city of Bangalore. It is also observed that during 01 March-23 March,
Fig. 3 Daily time series of the concentration of 6 major air pollutants observed over Bangalore during 01 March to 12 May 2020
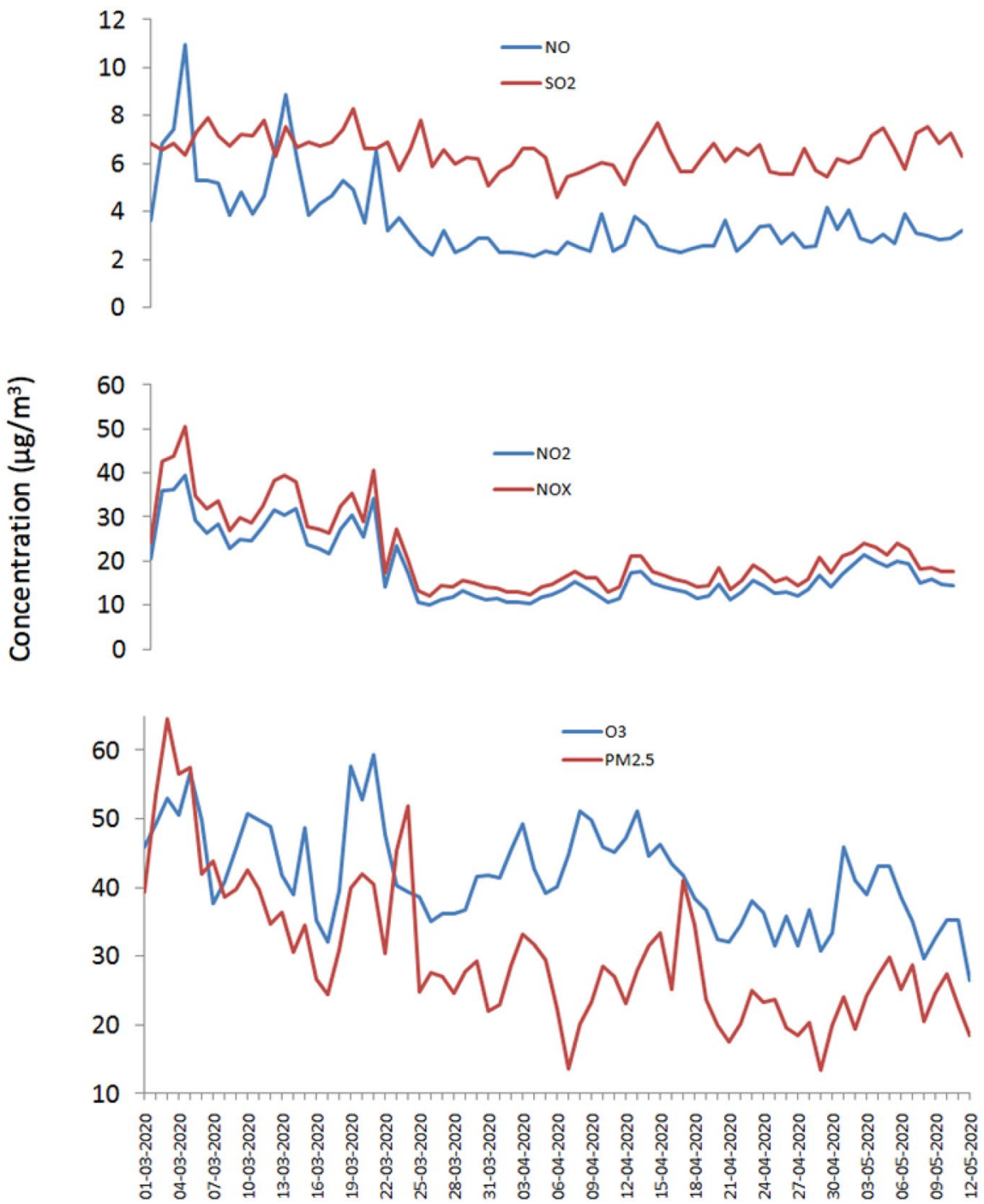
only 3 rainy days were observed, while it was 9 days during the lockdown period (24 March to 12 May). Similarly, the average temperature during the lockdown period (April-May 2020, summer) was $28^{\circ} \mathrm{C}$ as against $27.6^{\circ} \mathrm{C}$ in the pre-lockdown period. The average humidity during both pre-lockdown and lockdown period seems to be the same at around 53\%. During the lockdown period, the atmospheric condition was stable with moderate temperature and humidity, low wind speed $(0.8-1 \mathrm{~m} / \mathrm{s})$, and no intense rainfall. Thus, the prevailing atmospheric conditions over the city do not seem to be conducive for the quick dispersion of pollutants.
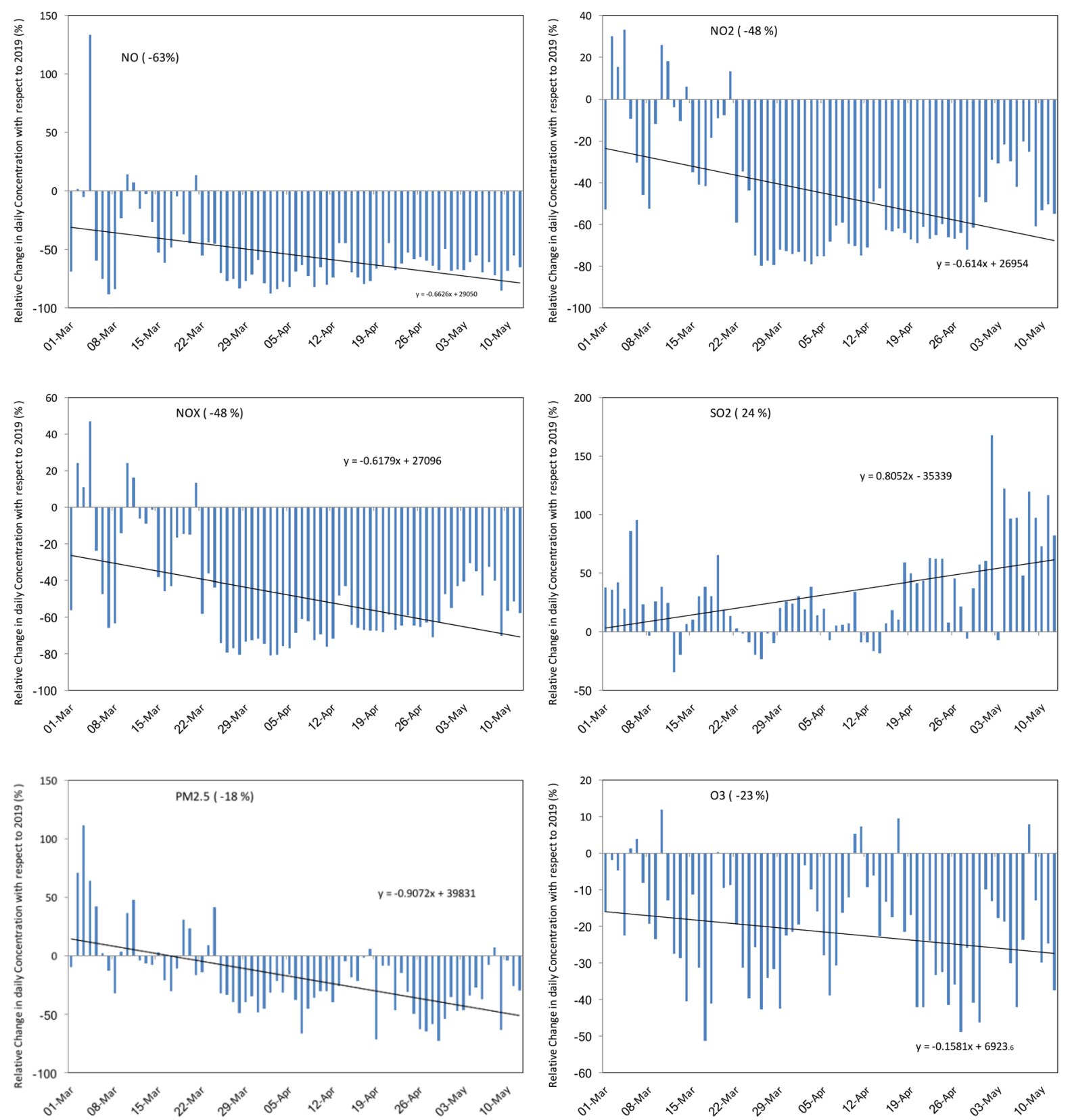

Fig. 4 Relative change in pollutant concentration over Bangalore from 01 March to 12 May 2020. The changes are shown as percent of corresponding concentrations in 2019. The average relative change for the whole period is presented in the bracket 
The daily average concentration of the six major air pollutants; $\mathrm{PM}_{2.5}, \mathrm{NO}_{\mathrm{X}}, \mathrm{NO}_{2}, \mathrm{NO}, \mathrm{SO}_{2}$, and $\mathrm{O}_{3}$ over Bangalore for the period 01 March to 12 May 2020 is shown in Fig. 3. It is inferred from the time series analysis that most of the pollutants show a decreasing (liner) trend during the period of analysis with a maximum for $\mathrm{PM}_{2.5}\left(-0.34 \mu \mathrm{g} / \mathrm{gm}^{3} /\right.$ day $)$; for $\mathrm{NO}_{\mathrm{X}}$ and $\mathrm{O}_{3}$, it is about $-0.2 \mu \mathrm{g} / \mathrm{gm}^{3} /$ day, and no trend for $\mathrm{SO}_{2}$, indicating the clear impact of lockdown on the daily concentration of the above atmospheric pollutants over Bangalore City.

The concentration of different pollutants is compared between two periods: 01 March to 12 May of 2019 and 2020. The daily relative percent change of pollutant concentration between the above two periods is computed using Eq. 1. The analysis presented in Fig. 4 shows a reduction in the concentration (73 days average) of all pollutants except $\mathrm{SO}_{2}$, coinciding with the implementation of lockdown. It is observed that $\mathrm{NO}, \mathrm{NO}_{2}, \mathrm{O}_{3}$, and $\mathrm{PM}_{2.5}$ concentrations are reduced by $63 \%, 48 \%, 48 \%, 23 \%$, and $18 \%$, respectively, in 2020 during the lockdown period as compared to the values during the same period in
2019. On the other hand, concentrations of $\mathrm{SO}_{2}$ are found to be increased by $24 \%$ during the lockdown period in 2020 when compared to the values during the same period in 2019. It is also observed that NO, $\mathrm{NO}_{2}, \mathrm{NO}_{\mathrm{X}}$, and $\mathrm{O}_{3}$ concentrations are lower for most of the time (50 days) during the lockdown period (24 March to 12 May 2020) when compared to the values in 2019 during the same period.

In the case of $\mathrm{O}_{3}, \mathrm{SO}_{2}$, and $\mathrm{PM}_{2.5}$ levels, during the lockdown period, observed concentrations on 46,12 , and 47 days are lower when compared to the corresponding days of 2019. This observation is also valid for the comparison of pollutant concentrations over weekends and working days between the two periods. This shows that there is a reduction in the pollutant concentration in 2020 during the lockdown period when compared to the same day in the previous year. The same analysis was also carried out on a weekly scale to reduce the influence of meteorology on atmospheric pollutants during the lockdown. As can be inferred from Fig. 5, except for $\mathrm{SO}_{2}$, all other pollutants show weekly reduction in the concentration relative to most of the corresponding weeks in 2019.

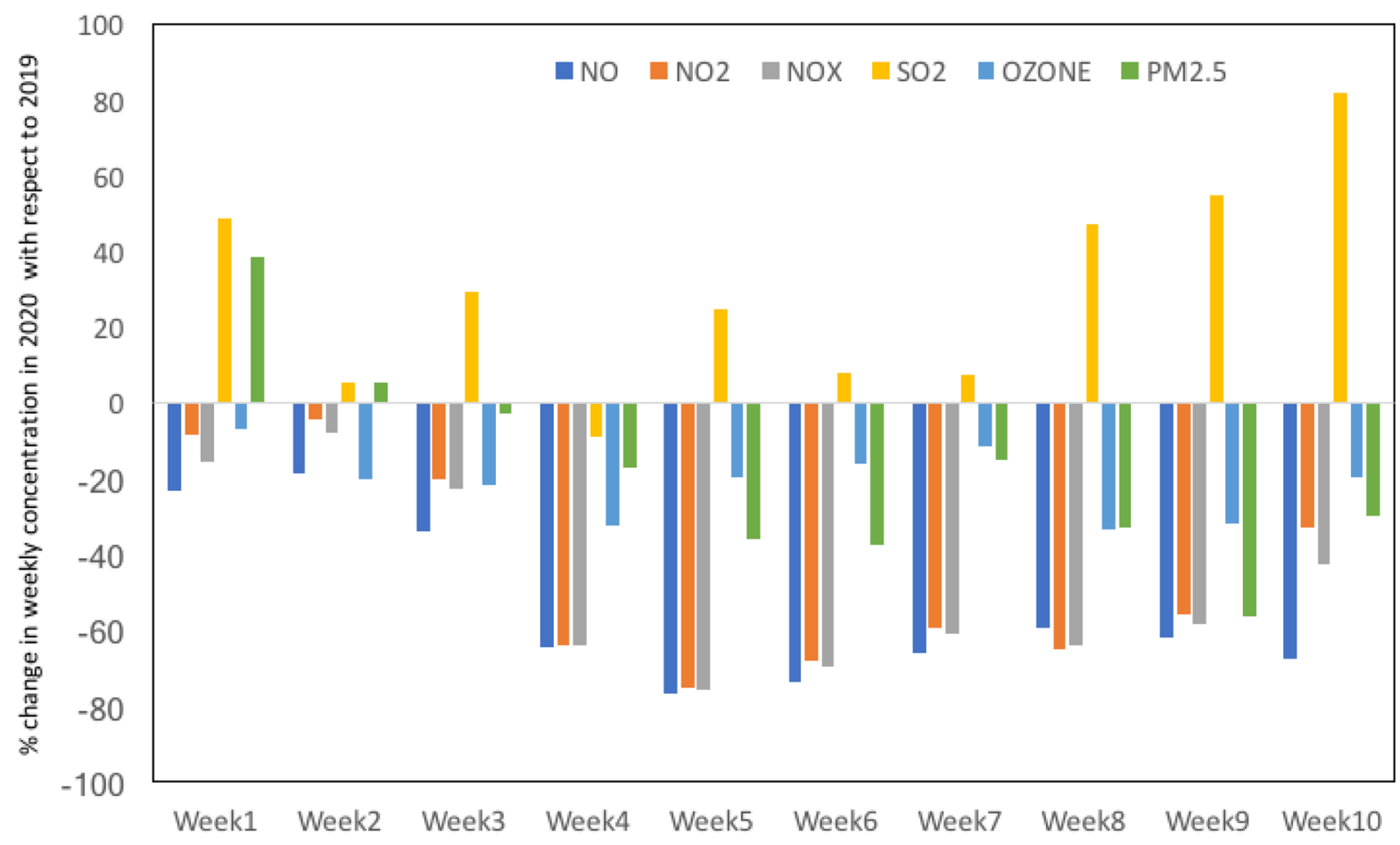

Fig. 5 Weekly relative percent change in pollutant concentration over Bangalore during 01 March-12 May 2020 with respect to same period of 2019 
The $\mathrm{PM}_{2.5}$ was increased only during the 1 st and $2 \mathrm{nd}$ week during the lockdown as compared to the same weeks in 2019, pointing to the direct impact of lockdown on ambient concentration of atmospheric pollutants in the Bangalore City.

The analysis of the spatial distribution of pollutants concentration between the periods 2020-2019 also shows that, both in the months of March and April, the changes are negative, implying that there was a net reduction in the concentration in 2020 during the lockdown period when compared to the same period in 2019. It is true for the changes in relative percentage too. In the case of $\mathrm{NO}_{2}$, the change is as low as $-50 \mu \mathrm{g} / \mathrm{m}^{3}$, but for $\mathrm{PM}_{2.5}$, the changes observed were as low as $-26 \mu \mathrm{g} / \mathrm{m}^{3}$ and $-57 \mu \mathrm{g} / \mathrm{m}^{3}$, respectively, for March and April 2020. In the case of relative percentage change, the range of $\mathrm{NO}_{2}$ concentration is about -83 to $40 \%$ (during March) and -93 to $40 \%$ in April. For $\mathrm{PM}_{2.5}$, the range of relative change is -48 to $10 \%$ and -84 to $-30 \%$ for March and April. respectively.
To assess the real impact of different lockdown phases on air quality over the city as a whole, the relative change in the pollutant concentration (CCL) during the lockdown as compared to pre-lockdown is presented as percent of pre-lockdown values in Fig. 6. During the whole phase of lockdown, i.e., 24 March to 12 May, there was a significant reduction in the concentration of $\mathrm{NO}, \mathrm{NO}_{2}, \mathrm{NO}_{\mathrm{X}}, \mathrm{SO}_{2}, \mathrm{PM}_{2.5}$, and $\mathrm{O}_{3}$ with $47.3 \%, 49.0 \%$, $49 \%, 10 \%, 37.4 \%$, and $15.6 \%$, respectively. All pollutants show significant reduction during the 1st lockdown except $\mathrm{O}_{3}$, which was only about $-8 \%$. The analysis of hourly ozone data for some locations indicate that the magnitude of $\mathrm{O}_{3}$ levels is a bit higher during the lockdown period in day times compared to the prelockdown period. This may be because of the summer temperature (Warminski \& Bes, 2018) and decreased titration by NO (Sicard et al., 2020). The decrease in pollution levels may be attributed to the fact that the lockdown was very strictly implemented with no traffic or any other construction or industrial activities. The concentrations started increasing during lockdown

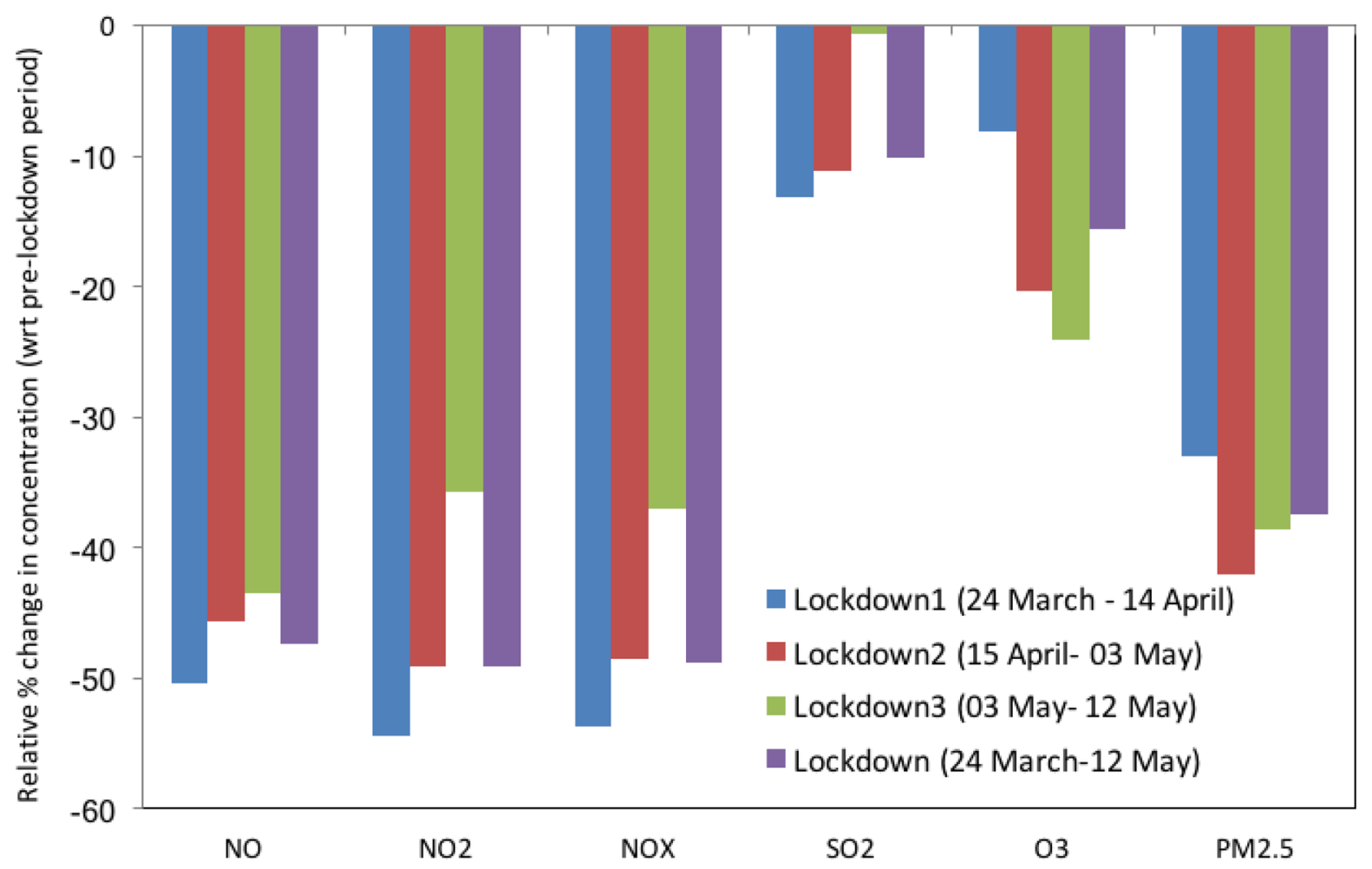

Fig. 6 Relative percent change in the pollutant concentration observed in whole Bangalore City during different phases of COVID19 lockdown for the pre-lockdown period in the year 2020 
2 and lockdown 3 when compared to lockdown 1 due to easing of restriction and subsequent movement of vehicles. Nevertheless, concentrations were still low compared to the pre-lockdown period (Fig. 6). Overall, the lockdown brought a reduction in the ambient air pollutants in the city during March-May 2020; this is in contrast with higher level pollution observed during the summer season. The same analysis was also carried out at each station to assess the region-wise impact of COVID-19 lockdown on the ambient concentration of air pollutants and the results are presented in Fig. 7. It is observed that the concentration of $\mathrm{NO}, \mathrm{NO}_{2}$, and $\mathrm{NO}_{\mathrm{X}}$ is very low at most stations during all phases of lockdown, but slightly increased in the station S5 and S8, which are located in the commercial area. Available $\mathrm{PM}_{2.5}$ data over 8 stations show relatively low values, indicating the reduction of pollutants during most phases of lockdown. But $\mathrm{SO}_{2}$ was reduced only in 4
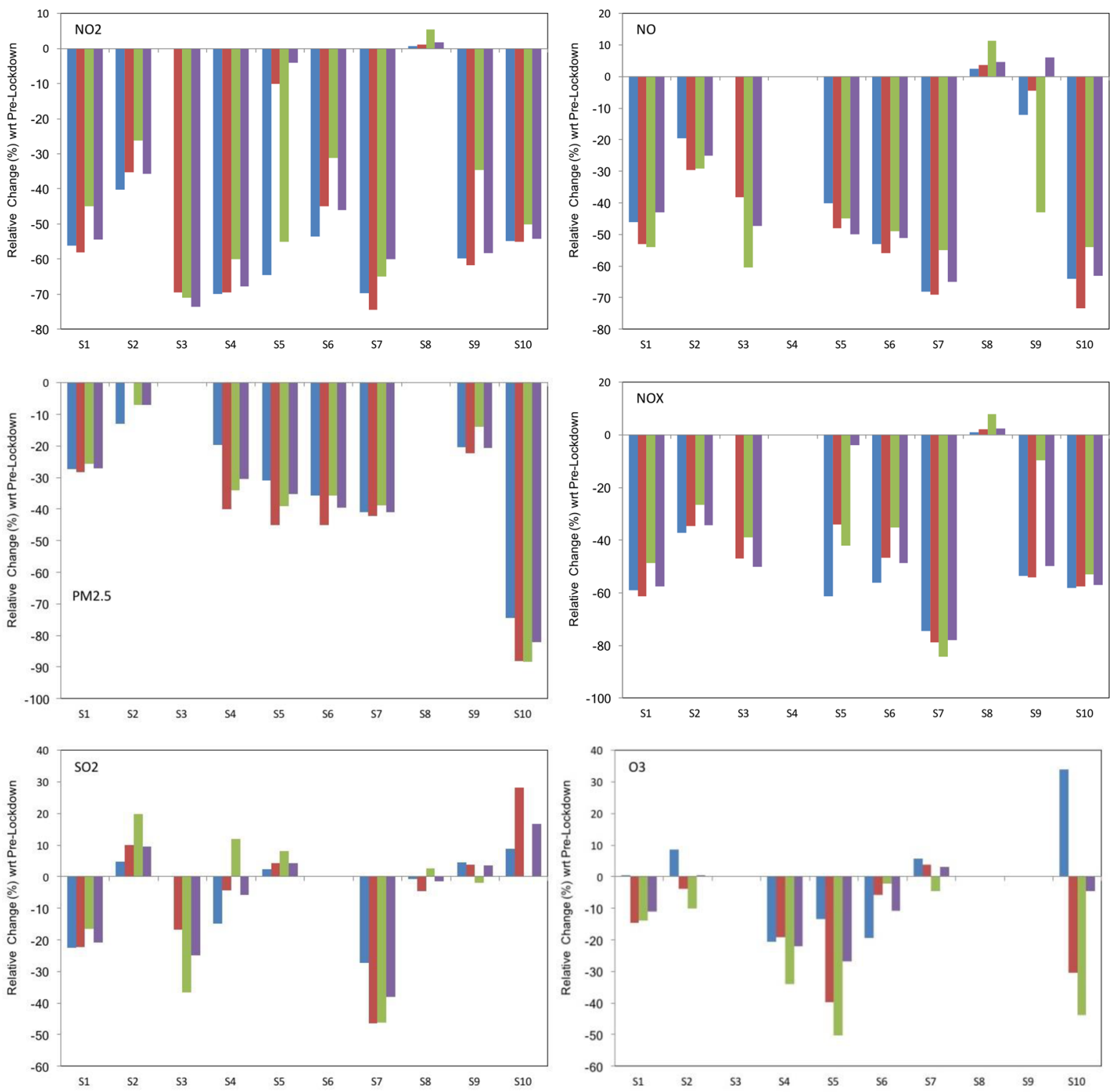

Fig. 7 Relative percent change in the pollutant concentration observed at 10 pollution monitoring stations in Bangalore during different phases of COVID-19 lockdown 
stations ( $\mathrm{S} 1, \mathrm{~S} 3, \mathrm{~S} 4$, and $\mathrm{S} 7$ ), and the concentration is high in the other 6 stations; this may be attributed to domestic cooking and vehicle movements of essential services as mentioned earlier. Similarly, the trend of $\mathrm{O}_{3}$ concentration also decreased in all stations except for station S10 which is located in the industrial area. The average trend in all industrial stations (S4, S7, S9, and S10) shows greater reduction in the pollution concentrations than the commercial stations (S1, S2, S5, S6, and S8), indicating the role of lockdown in reducing the ambient concentration of air pollutants and improved air quality over the Bangalore City.

\section{Conclusions}

In this study, the variation in the ambient concentration of major air pollutants $\left(\mathrm{NO}, \mathrm{NO}_{2}, \mathrm{NOX}, \mathrm{PM} 2.5, \mathrm{O}_{3}\right.$, and $\mathrm{SO}_{2}$ ) across 10 monitoring stations over Bangalore City in India is compared at daily and monthly intervals for the period of March-May for the years 2019 and 2020. The main objective was to study the impact of COVID-19 pandemic-induced lockdown on ambient air quality (AAQ) at a city scale. The impact of lockdown is shown to be remarkable in improving the air quality with a significant reduction in the ambient concentration of air pollutants: $\mathrm{NO}(-63 \%), \mathrm{NO}_{2}(-48 \%), \mathrm{NO}_{\mathrm{X}}$ $(-48 \%)$, and $\mathrm{O}_{3}(-23 \%)$ during the lockdown period when compared to the same period in 2019. The spatial analysis also witnessed significant improvement in the air quality throughout the city during the lockdown. In Bangalore, to a large extent, the decline in road traffic resulted in a significant decrease (48-63\%) in the levels nitrogen oxides $\left(\mathrm{NO}_{2}, \mathrm{NO}_{\mathrm{X}}\right.$, and $\left.\mathrm{NO}\right)$. Also, the comparison of concentrations during the lockdown and pre-lockdown period shows that the lockdown period (2020) witnessed a significant reduction by $47.3 \%$ (NO), $49 \%\left(\mathrm{NO}_{2}\right), 49 \%\left(\mathrm{NO}_{\mathrm{X}}\right), 10 \%\left(\mathrm{SO}_{2}\right), 37.7 \%\left(\mathrm{PM}_{2.5}\right)$, and $15.6 \%\left(\mathrm{O}_{3}\right)$ over Bangalore. These sharp reductions during April and May 2020 can be attributed to a reduction in industrial and traffic activities. The stationlevel analysis supported the widespread reduction of pollutants across the city. In a nutshell, the COVID-19 lockdown resulted in improved air quality over Bangalore City. This type of observational studies can be integrated with model predictions to assess the impact of intervention strategies and help environmental monitoring and regulating agencies to achieve their objective of air quality compliance.
Acknowledgements The CSIR 4PI high-performance computing (HPC) facility used for computing is thankfully acknowledged. The authors acknowledge Head, CSIR 4PI for support and encouragement. The authors acknowledge CPCB and $\mathrm{KSPCB}$, Bangalore, for providing the air quality data used in this study.

Funding This work is supported by the projects funded by the Department of Science and Technology under Epidemiology Data Analytics (EDA) of Interdisciplinary Cyber-Physical Systems (ICPS) program (grant no. DST/ICPS/EDA/2018), the DST-RFBR project on Analysis of urban heat islands, air pollution dynamics, and extreme weather phenomena in India and Russia (grant no. INT/RUS/RFBR/P-336 2019) Government of India, and another project funded under National Mission on Himalayan Studies (NMHS) of Ministry of Environment, Forest and Climate Change, Government of India (grant no. GBPNI/NMHS-2019-20/MG/315).

Data availability Data will be available on reasonable request.

\section{Declarations}

Conflict of interest The authors declare no competing interests.

\section{References}

Agarwal, R., Jayaraman, G., Anand, S., \& Marimuthu, P. (2006). Assessing respiratory morbidity through pollution status and meteorological conditions for Delhi. Environmental Monitoring and Assessment, 114, 489-504.

Arden Pope, C., Burnett Richard, T., Thurston George, D., Thun Michael, J., Calle Eugenia, E., et al. (2004). Cardiovascular mortality and long-term exposure to particulate air pollution. Circulation, 109, 71-77.

Atkinson, RW., Butland, BK., Anderson, HR., Maynard, RL. (2018). Long term concentrations of nitrogen dioxide and mortality: A meta analysis of cohort studies. Epidemiology 29(4):460472.

Bashir, MF., Ma, B., Komal, B., Bashir, MA., Tan, D., Bashir, M. (2020). Correlation between climate indicators and COVID-19 pandemic in New York, USA. Science of the Total Environment, 728, 138835. https://doi.org/10. 1016/j.scitotenv.2020.138835

Bera, B., Bhattacharjee, S., Shit, P. K., Sengupta, N., \& Saha, S. (2020). Significant impacts of COVID-19 lockdown on urban air pollution in Kolkata (India) and amelioration of environmental health. Environment Development and Sustainability, 2020, 1-28. https://doi.org/10.1007/ s10668-020-00898-5

CPCB. (2003a). Guidelines for ambient air quality monitoring series: NAAQMS/.../2003-04. Central Pollution Control Board, https://tinyurl.com/y8r54a3z Accessed 6 Nov 2020.

CPCB. (2003b). Guidelines for ambient air quality monitoring series: NAAQMS/.../2003-04. Central Pollution Control Board, https://tinyurl.com/ycjs4h8j Accessed 6 Nov 2020

CPCB. (Central Pollution Control Board) (2010). Air quality monitoring, emission inventory and source apportionment 
study for Indian cities, National Summary Report. The Central Pollution Control Board, New Delhi, India, 290pages.

CPCB. (Central Pollution Control Board) (2014). http://cpcb. nic.in/air.php. accessed in 15 June 2020.

Cui, Y., Zhang, Z. F., Froines, J., et al. (2003). Air pollution and case fatality of SARS in the People's Republic of China: An ecologic study. Environmental Health, 2(1), 15.

Devara, P., et al. (2020). Influence of air pollution on coronavirus (COVID-19): Some evidences from studies at AUH, Gurugram, India. Science Total Environment. https://doi.org/10.2139/ssrn.3588060

Faustini, A., Rapp, R., \& Forastiere, F. (2014). Nitrogen dioxide and mortality: Review and meta-analysis of long-term studies. European Respiratory Journal, 44(3), 744-753.

Garaga, R., Sahu, S. K., \& Kota, S. H. (2018). A review of air quality modeling studies in India: Local and regional scale. Current Pollution Reports, 4, 59-73.

Gautam, S. (2020). COVID-19: Air pollution remains low as people stay at home. Air Quality, Atmosphere and Health, 21, 1-5.

Gouda KC, Nikhilasuma P, Kumari R, Singh P, Benke, M., et al. (2020). Analysing spatio-temporal spread of Covid19 in India. COVID-19 Pandemic: Case Studies \& Opinions 01(04): 57-67.

Global Carbon Project. (2020). Global carbon project. https://www. globalcarbonproject.org/carbonbudget/index.htm

Gordon, T., Balakrishnan, K., Dey, S., Rajagopalan, S., Thornburg, J., Thurston, G., Agrawal, A., Collman, G., Guleria, R., Limaye, S., Salvi, S., Kilaru, V., \& Nadadur, S. (2018). Air pollution health research priorities for India: Perspectives of the Indo-U.S. Communities of Researchers. Environment International, 119, 100-108.

Guttikunda, S. K., Nishadh, K. A., Gota, S., Singh, P., Chanda, A., Jawahar, P., \& Asundi, J. (2019). Air quality, emissions, and source contributions analysis for the Greater Bengaluru region of India. Atmospheric Pollution Research, 10(3), 941-953.

He, G., Pan, Y., Tanaka, T. (2020). COVID-19, city lockdown, and air pollution: Evidence from China. MedRxiv. https:// doi.org/10.1101/2020.03.29.20046649

Holzworth, G. C. (1967). Mixing depths, wind speeds and air pollution potential for selected locations in the United States. Journal of Applied Meteorology, 6, 1039-1044.

Humbal, C., Gautam, S., et al. (2019). Evaluating the colonization and distribution of fungal and bacterial bioaerosol in Rajkot, western India using multi-proxy approach. Air Quality, Atmosphere and Health, 12(6), 693-704.

Isaifan, R. J. (2020). The dramatic impact of coronavirus outbreak on air quality: Has it saved as much as it has killed so far? Global Journal of Environment Science and Management, 6(3), 275-288.

Koken, P. J., Piver, W. T., Ye, F., Elixhauser, A., Olsen, L. M., \& Portier, C. J. (2003). Temperature, air pollution and hospitalization for cardiovascular diseases among elderly people in Denver. Environmental Health Perspectives, 111(10), 1312-1317.

Kota, S. H., Guo, H., Myllyvirta, L., Hu, J., Sahu, S. K., Garaga, R., et al. (2018). Year-long simulation of gaseous and particulate air pollutants in India. Atmospheric Environment, 180, 244-255.
Kulmala, M., Vehkamaki, H., Petaja, T., Dal Maso, M., Lauri, A., Kerminen, V. M., Birmili, W., \& McMurry, P. H. (2004). Formation and growth rates of ultrafine atmospheric particles: A review of observations. Journal of Aerosol Science, 35, 143-176.

Leggett, T. (2020). Coronavirus: Global growth 'could halve' if outbreak intensifies. BBC. Retrieved https://bbc.com/ news/business51700935 (accessed in 25April 2020).

Le Tertre, A., Medina, S., Samoli, E., Forsberg, B., Michelozzi, P., Boumghar, A., Vonk, J. M., Bellini, A., Atkinson, R., Ayres, J. G., Sunyer, J., Schwartz, J., \& Katsouyanni, K. (2002). Short-term effects of particulate air pollution on cardiovascular diseases in eight European cities. Journal of Epidemiology and Community Health, 56, 773-779.

Lelieveld, J., Evans, J. S., Fnais, M., Giannadaki, D., \& Pozzer, A. (2015). The contribution of outdoor air pollution sources to premature mortality on a global scale. Nature, 525(7569), 367-371.

Lewis, D. (2020). Is the coronavirus airborne? Experts Can't Agree. Nature News, 580, 175.

Li, Q., Guan, X., Wu, P., Wang, X., Zhou, L., Tong, Y., Ren, R., Leung, K., Lau, E., Wong, J., et al. (2020). Early transmission dynamics in Wuhan, China, of novel coronavirusinfected pneumonia. New England Journal of Medicine, 382, 1199-1207.

Mahato, S., Pal, S., Ghosh, K. G. (2020). Effect of lockdown amid COVID-19 pandemic on air quality of the megacity Delhi, India. Science of the Total Environment. 730, 139086.

Ministry of Health and Family Welfare, Government of India COVID-19 India dashboard. (2020). https://www.mohfw. gov.in. Accessed July, 24, 2020.

Mitra, A., Chaudhuri, T. R., Mitra, A., Pramanick, P., Zaman, S., Mitra, A., Chaudhuri, T. R., Mitra, A., Pramanick, P., \& Zaman, S. (2020). Impact of COVID-19 related shutdown on atmospheric carbon dioxide level in the city of Kolkata. Science and Education, 6, 84-52.

Morawskaa, L., Cao, J. (2020). Airborne transmission of SARSCoV-2: The world should face the reality. Environment International, 139:105730.

Morales, K. F., Paget, J., \& Spreeuwenberg, P. (2009). Possible explanations for why some countries were harder hit by the pandemic influenza virus in 2009-A global mortality impact modeling study. BMC Infectious Diseases, 17, 642.

Mukherjee, A., \& Agrawal, M. (2018). Air pollutant levels are 12 times higher than guidelines in Varanasi, India. Sources and Transfer. Environmental Chemistry Letters, 16, 1009-1016.

Myhre, G., Shindell, D., Bréon, F. M., Collins, W., Fuglestvedt, J., Huang, J., Koch, D., Lamarque, J. F., Lee, D., Mendoza, B., Nakajima, T. (2013). Anthropogenic and natural radiative forcing. In: Climate change 2013: The physical science basis. In T. F. Stocker et al (Eds.), Contribution of working group I to the fifth assessment report of the intergovernmental panel on climate change. Cambridge University Press. Pp 659-740.

Nasir, H., Goyal, K., \& Prabhakar, D. (2016). Review of air quality monitoring: Case study of India. Indian Journal of Science and Technology, Vol 9(44).

Persinger, R. L., Poynter, M. E., Ckless, K., \& Janssen-Heininger, Y. M. W. (2002). Molecular mechanisms of nitrogen dioxide 
induced epithelial injury in the lung. Molecular and Cellular Biochemistry, 234, 71-80.

Saeha, S., Bai, L., et al. (2020). Association between road traffic noise and incidence of diabetes mellitus and hypertension in Toronto, Canada: a population-based cohort study. Journal of the American Heart Association 9:013021.

Sicard, P., De Marco, A., Agathokleous, E., Feng, Z., Xu, X., Paoletti, E., et al. (2020). Amplified ozone pollution in cities during the COVID-19 lockdown. Science of the Total Environment, Article 139542.

Sharma, S., et al. (2020). Effect of restricted emissions during COVID-19 on air quality in India. Science of the Total Environment, 728:138878.

Shair, F. H. (1974). Dispersion of an instantaneous cross-Wind line source of tracer release. Atmospheric Environment, 8, 475-485.

Singal, S. P., \& Prasad, R. (2005). Analytical study of some observed micro meteorological data. Journal of the Air Pollution Control Association, 1, 44-49.

State Disaster Management Authority: Government of Karnataka. (2020). Karnataka COVID 19 Dash- board Website. https:// covid19.karnataka.gov.in/covid-dashboard/dashboard.html. Accessed Dec 24, 2020.
Tayanc, M. (2000). An assessment of spatial and temporal variation of sulfur dioxide levels over Istanbul, Turkey. Environmental Pollution, 107, 61-69.

Venkata, S. R., Giridhara, R. B., Prabhakaran, D. (2020). COVID-19 pandemic in Mahatodia: Is the curve now flat? European Heart Journal, ehaa493. https://doi.org/10. 1093/eurheartj/ehaa493

Vijay B, B., \& Mehta, V. M. (2010). Atmospheric particulate pollutants and their relationship with meteorology in Ahmedabad. Aerosol and Air Quality Research, 10, 301-315.

Warmiński, K., \& Bęś, A. (2018). Atmospheric factors affecting a decrease in the night-time concentrations of tropospheric ozone in a low-polluted urban area. Water Air Soil Pollution, 229, 350. https://doi.org/10.1007/s11270-018-4012-x

World Health Organization (2020). Novel coronavirus (2019$\mathrm{nCoV})$, Situation reports.

Publisher's Note Springer Nature remains neutral with regard to jurisdictional claims in published maps and institutional affiliations. 